\begin{tabular}{llrr}
\hline \hline Volume: & 2 & E-ISSN: & $2655-1942$ \\
Number: & 2 & Terbitan: & November 2019 \\
Page : & $194-211$ & & \\
\hline
\end{tabular}

\title{
Peran Otoritas Jasa Keuangan (OJK) Dalam Hal Perlindungan
} Nasabah Pada Lembaga Keuangan Mikro Syariah

\author{
Aisyah Ayu Musyafah \\ Fakultas Hukum Universitas Diponegoro \\ aisyahayumusyafah@gmail.com
}

\begin{abstract}
Abstrak
Otoritas Jasa Keuangan atau OJK sebagai lembaga pengawas lembaga keuangan bertugas untuk melakukan pengawasan terhadap lembaga keuangan di Indonesia. Lembaga keuangan disini termasuk lembaga keuangan mikro dengan basis syariah. Salah satu tujuan pengawasan OJK ini adalah melindungi nasabah dari berbagai permasalahan dengan lembaga keuangan. Pada penelitian ini akan difokuskan mengenai peran OJK dalam perlindungan nasabah pada lembaga keuangan mikro syariah. Penelitian ini merupakan penelitian yuridis normatif dengan sifat penelitian deskriptif. Hasil dari penelitian ini adalah diketahui bahwa peran OJK dalam hal perlindungan nasabah adalah dalam bentuk pelayanan pengaduan Konsumen yang meliputi penyiapan perangkat yang memadai, membuat mekanisme pengaduan Konsumen, dan memfasilitsi penyelesaian pengaduan.

Kata kunci: Otoritas Jasa Keuangan, Lembaga Keuangan Mikro Syariah, Lembaga
\end{abstract} Keuangan, Syariah

\begin{abstract}
Otoritas Jasa Keuangan (OJK) as a financial institution supervisory agency is tasked with supervising financial institutions in Indonesia. Financial institutions here include sharia-based microfinance institutions. One of the objectives of OJK supervision is to protect customers from various problems with financial institutions. This research will focus on the role of OJK in protecting customers in Islamic microfinance institutions. This research is a normative juridical study with the nature of descriptive research. The results of this study are known that the role of OJK in terms of customer protection is in the form of Consumer complaint services which include the preparation of adequate equipment, creating a Consumer complaints mechanism, and facilitating the resolution of complaints
\end{abstract}

Keyword: Otoritas Jasa Keuangan, Islamic microfinance institutions, microfinance, syaria 


\begin{tabular}{llrr}
\hline \hline Volume: & 2 & E-ISSN: & $2655-1942$ \\
Number: & 2 & Terbitan: & November 2019 \\
Page : & $194-211$ & & \\
\hline
\end{tabular}

\section{A. Latar Belakang Masalah}

Salah satu solusi meningkatkan pertumbuhan perekonomian nasional dan mengurangi angka kemiskinan di Indonesia adalah dengan pemberdayaan usaha mikro, kecil, dan menengah (UMKM). Namun dalam melaksanakan upaya tersebut, UMKM kerap kali terkendala dengan akses pendanaan ke lembaga keuangan yang formal. Akan tetapi dengan banyaknya pertumbuhan dan perkembangan lembaga keuangan non-bank yang melakukan kegiatan usaha jasa pengembangan usaha dan pemberdayaan masyarakat, baik yang didirikan oleh pemerintah atau masyarakat. Lembaga-lembaga tersebut biasa kita kenal sebagai Lembaga Keuangan Mikro (LKM). Perkembangan Lembaga Keuangan Mikro dimulai sejak akhir tahun 1990an, memiliki tujuan antara lain, menciptakan kesempatan kerja dan pendapatan melalui penciptaan dan pengembangan usaha mikro, meningkatkan daya produksi usaha mikro, mengurangi keterikatan masyarakat pedesaan terhadap panen yang beresiko gagal karena musim kemarau melalui penggolongan kegiatan usaha kecil yang dapat menghasilkan pendapatan. ${ }^{1}$

Sebagai negara dengan mayoritas masyarakat beragama muslim, Indonesia dapat dengan mudah menerima perkembangan perekonomian dengan sistem syariah. Hal ini terlihat dari meningkatnya jumlah produk-poduk investasi syariah maupun pembiayaan syariah.

Lembaga keuangan mikro syariah termasuk ke dalam pembiayaan syariah masuk dalam kategori Industri keuangan Non-bank (IKNB) syariah yang diawasi oleh Otoritas Jasa Keuangan (OJK), dimana seluruhnya mencakup berbagai sektor, mulai dari perusahaan perasuransian syariah, dana pensiun syariah, lembaga pembiayaan syariah, dan lembaga keuangan syariah khusus serta lembaga keuangan mikro (LKM) syariah. ${ }^{2}$

Lembaga keuangan mikro syariah yang merupakan LKM yang beroperasi berdasarkan prinsip-prinsip syariah, kegiatan yang dilakukan adalah bukan dalam

\footnotetext{
${ }^{1}$ Arsyad, Lincolin. 2008. Lembaga Keuangan Mikro Institusi Kinerja dan Sustanbilitas. Yogyakarta: Andi., hlm.

${ }^{2}$ OJK (2015), Roadmap Industri Keuangan Non-Bank (IKNB) Syariah 2015-2019
} 


\begin{tabular}{llrr}
\hline \hline Volume: & 2 & E-ISSN: & $2655-1942$ \\
Number: & 2 & Terbitan: & November 2019 \\
Page : & $194-211$ & & \\
\hline
\end{tabular}

bentuk simpanan melainkan berupa pembiayaan. Pembiayaan di sini dapat diartikan sebagai penyediaan dana kepada masyarakat yang harus dikembalikan sesuai dengan perjanjian yang disepakati menurut prinsip simpanan. Dalam menjalankan kegiataannya lembaga keuangan mikro syariah haruslah merujuk kepada fatwa yang dikeluarkan oleh Dewan Syariah Nasional Majelis Ulama Indonesia (DSN-MUI). Untuk mengawasi kegiatan lembaga keuangan mikro syariah sesuai dengan prinsip syariah serta memberi nasihat dan saran kepada direksi atau pengurusnya, lembaga keuangan mikro syariah wajib membentuk Dewan Pengawas Syariah (DPS).

Menurut Philipus M. Hadjon perlindungan hukum merupakan perlindungan akan harkat dan martabat serta pengakuan terhadap hak asasi manusia yang dimiliki oleh subyek hukum dalam Negara hukum dengan berdasarkan pada ketentuan hukum yang berlaku di Negara tersebut guna mencegah terjadinya kesewenang-wenangan, sehingga dapat dikatakan bahwa hukum berfungsi sebagai perlindungan atas kepentingan manusia. ${ }^{3}$

Dengan berkembangnya lembaga keuangan mikro syariah, pemerintah mengeluarkan Undang-Undang Nomor 1 tahun 2013 Tentang Lembaga Keuangan Mikro (UU-LKM) untuk melindungi status kelembagaan lembaga tersebut. Sebelum diundangkannya UU-LKM, aktivitas LKM di Indonesia kerap kali dianggap bermasalah dan tidak memiliki kepastian hukum.

Agar dapat beroperasi, lembaga keuangan syariah harus mendapat izin terlebih dahulu dari Otoritas Jasa Keuangan (OJK). LKM yang akan beroperasi juga harus mengajukan permohonan untuk mendapat izin usaha dari OJK semenjak diberlakukannya UU-LKM. Selain berwenang menberikan izn kepada LKM, OJK juga berwenang untuk melakukan pembinaan, pengaturan dan pengawasan terhadap LKM, baik yang berbadan hukum koperasi dan perseroan terbatas, dimana pengawasan merupakan salah satu strategi/cara bagi OJK dalam menjalankan salah satu fungsinya yaitu fungsi perlindungan konsumen/nasabah. Pada Penelitian ini, akan difokuskan mengenai bagaimana Urgensitas perlindungan hukum terhadap

\footnotetext{
${ }^{3}$ Hadjon, Philipus M. 1987. Perlindungan Hukum Bagi Rakyat Indonesia. Surabaya: Bina Ilmu.
} 


\begin{tabular}{llrr}
\hline \hline Volume: & 2 & E-ISSN: & $2655-1942$ \\
Number: & 2 & Terbitan: & November 2019 \\
Page : & $194-211$ & & \\
\hline
\end{tabular}

nasabah penyimpan dana Lembaga keuangan Syariah dan bagaimana peran OJK dalam perlindungan nasabah pada lembaga keuangan mikro syariah.

\section{B. Metode Penelitian}

Jenis penelitian ini adalah penelitian yuridis normatif. Penelitian yuridis normatif merupakan suatu kegiatan ilmiah yang berdasarkan pada metode, sistematika dan pemikiran tertentu yang bertujuan untuk mempelajari sesuatu atau beberapa gejala hukum tertentu, dengan jalan menganalisisnya. ${ }^{4}$ Penelitian yuridis normatif disebut juga sebagai penelitian kepustakaan atau studi dokumen karena penelitian ini dilakukan atau ditujukan hanya pada peraturan-peraturan yang tertulis atau bahan-bahan hukum yang lain. ${ }^{5}$

Sifat penelitian ini merupakan penelitian hukum deskriptif (descriptive legal study). Penelitian hukum deskriptif maksudnya adalah, bahwa peneliti dalam menganalisis berkeinginan untuk memberikan gambaran atau pemaparan atas subjek dan objek penelitian sebagaimana hasil penelitian yang dilakukannya dan disini peneliti tidak melakukan justifikasi terhadap hasil penelitiannya tersebut. ${ }^{6}$ Penelitian ini juga dimaksudkan untuk eksplorasi dan klarifikasi mengenai suatu fenomena atau kenyataan sosial, dengan jalan mendeskripsikan sejumlah variabel yang berkenaan dengan masalah dan unit yang diteliti antara fenomena yang diuji.

\section{Hasil Penelitian dan Pembahasan}

1. Urgensitas perlindungan hukum terhadap nasabah penyimpan dana Lembaga keuangan Syariah Dalam pembahasan pada bab ini yang menjelaskan terkait manfaat

\footnotetext{
${ }^{4}$ Soejono dan H Abdurrahman, 1999, Metode Penelitian Suatu Pemikiran dan Penerapan, Rineke Cipta, Jakarta, hlm. 110 .

${ }^{5}$ Soerjono Soekanto dan Sri Mamudji, 2007, Penelitian Hukum Normatif, PT Raja Grafindo Persada, Jakarta, hlm. 14.

${ }^{6}$ Peter Mahmud Marzuki, 2005, Penelitian Hukum, Prenadamedia Group, Jakarta, hlm. 191.
} 


\begin{tabular}{llrr}
\hline \hline Volume: & 2 & E-ISSN: & $2655-1942$ \\
Number: & 2 & Terbitan: & November 2019 \\
Page : & $194-211$ & & \\
\hline
\end{tabular}

Lembaga Keuangan Mikro Syariah yang diperoleh masyarakat khususnya nasabah penyimpan, berdasarkan kepercayaan yang mereka berikan kepada Lembaga Keuangan Mikro Syariah sebagai lembaga perantara keuangan dalam skala mikro untuk keberlangsungan usaha mereka dan simpanan yang mereka titipkan.

a. Analisis pengaturan Hukum bagi nasabah penyimpan Lembaga keuangan mikro syariah

Perlindungan hukum diberikan kepada nasabah penyimpan atas simpanannya. Perlindungan hukum bagi nasabah penyimpan telah diatur dalam berbagai bentuk peraturan perundang-undangan. Namun, beberapa dari peraturan tersebut tidak mengatur terkait perlindungan nasabah penyimpan Lembaga Keuangan Mikro yang bertujuan untuk memberikan jaminan atas kerugian finansial yang dirasakan para nasabah penyimpan.

Perlindungan hukum diberikan kepada nasabah penyimpan atas simpanannya. Perlindungan hukum bagi nasabah penyimpan telah diatur dalam berbagai bentuk peraturan perundang-undangan. Namun, beberapa dari peraturan tersebut tidak mengatur terkait perlindungan nasabah penyimpan Lembaga Keuangan Mikro yang bertujuan untuk memberikan jaminan atas kerugian finansial yang dirasakan para nasabah penyimpan.

1) Undang-undang Republik Indonesia Nomor 21 Tahun 2011 Tentang Otoritas Jasa Keuangan (Lembaran Negara Republik Indonesia Tahun 2011 Nomor 111, Tambahan Lembaran Negara Republik Indonesia Nomor 5253) Undang-undang ini mengatur tentang fungsi, tugas dan wewenang pengaturan dan pengawasan terhadap kegiatan di dalam sektor jasa keuangan. Pengaturan terkait perlindungan hukum bagi konsumen dan masyarakat terdapat dalam BAB VI Perlindungan Konsumen dan Masyarakat 


\begin{tabular}{llrr}
\hline \hline Volume: & 2 & E-ISSN: & $2655-1942$ \\
Number: & 2 & Terbitan: & November 2019 \\
Page : & $194-211$ & & \\
\hline
\end{tabular}

Pasal 28, 29, 30 dan 31.

Berdasarkan Pasal 29 tersebut diatas, salah satu wewenang OJK dalam melakukan perlindungan terhadap konsumen ialah membuat mekanisme pengaduan konsumen dalam lembaga jasa keuangan, maka dapat diartikan bahwa OJK juga berwenang untuk membuat mekanisme pengaduan nasabah penyimpan Lembaga Keuangan Mikro sebagai salah satu lembaga jasa keuangan. Hal ini juga berdasarkan peralihan sebagian tugas dan wewenang Bank Indonesia kepada OJK dalam hal mengawasi lembaga keuangan yang telah dijelaskan dalam Pasal 69 ayat (1) yang menjelaskan bahwa tugas Bank Indonesia dalam mengatur dan mengawasi Bank yang dialihkan kepada OJK terkait tugas pengaturan dan pengawasan yang berkaitan dengan microprudential yaitu tentang kelembagaan, kesehatan lembaga jasa keuangan, aspek kehatihatian dan pemeriksaan bank, sedangkan Bank Indonesia tetap memiliki tugas perbankan terkait macroprudential yakni selain hal yang ditetapkan sebagai microprudential dalam undang-undang ini.

2) Undang-undang Republik Indonesia Nomor 1 Tahun 2013 Tentang Lembaga Keuangan Mikro (Lembaran Negara Republik Indonesia Tahun 2013 Nomor 12, Tambahan Lembaran Negara Republik Indonesia Nomor 5394)

Undang-undang Nomor 1 Tahun 2013 Tentang Lembaga Keuangan Mikro merupakan peraturan perundang-undangan yang mengatur tentang Lembaga Keuangan Mikro. Pengaturan terkait perlindungan hukum bagi nasabah penyimpan terdapat dalam BAB VIII tentang perlindungan pengguna jasa LKM Pasal 24, 25 dan 26.

3) Peraturan Otoritas Jasa Keuangan Nomor 1/POJK.07/2013 Tentang Perlindungan Konsumen Sektor Jasa Keuangan Peraturan ini dibentuk berdasarkan amanah dari Pasal 31 Undang-undang Nomor 
Law, Development \& Justice Review

\begin{tabular}{llrr}
\hline \hline Volume: & 2 & E-ISSN: & $2655-1942$ \\
Number: & 2 & Terbitan: & November 2019 \\
Page : & $194-211$ & & \\
\hline
\end{tabular}

21 Tahun 2011 Tentang Otoritas Jasa Keuangan, perlu ditetapkan

Peraturan Ooritas Jasa Keuangan tentang Perlindungan Konsumen

Sektor Jasa Keuangan. 
b. Kedudukan nasabah penyimpan Lembaga keuangan mikro Syariah berdasarkan konstruksi hukum perjanjian

Pada Undang-undang Nomor 1 Tahun 2013 Tentang Lembaga Keuangan Mikro merumuskan pengertian penyimpan dalam Pasal 1 angka 5, yaitu pihak yang menempatkan dananya pada Lembaga Keuangan Mikro berdasarkan perjanjian. ${ }^{7}$

Berdasarkan Pasal 1313 Kitab Undang-undang Hukum Perdata dinyatakan bahwa suatu perjanjian merupakan suatu perbuatan dimana satu orang lebih mengikatkan dirinya terhadap satu orang lain atau lebih. Sehingga jelas hubungan hukum antara nasabah penyimpan dana dengan Lembaga Keuangan Mikro Syariah terjadi karena diawali dengan persetujuan kedua belah pihak membuat perjanjian.

Menurut Pasal 1338 ayat (1) Kitab Undang-undang Hukum Perdata, menyebutkan bahwa semua perjanjian yang dibuat secara sah berkekuatan sama dengan undang-undang bagi kedua belah pihak.

Berbeda dengan nasabah pinjaman/pembiayaan, untuk nasabah penyimpan tidak terdapat ketentuan yang khusus mengatur terkait perjanjian penitipan simpanan dana, karena itu perjanjian simpanan dana tunduk pada ketentuan umum dari Kitab Undang-Undang Hukum Perdata mengenai perikatan. Disamping itu, berbeda dengan perjanjian untuk nasabah pinjaman/pembiayaan, perjanjian ini seringnya diatur secara komprehensif, sedangkan untuk nasabah penyimpan dana lazimnya diatur secara sederhana dalam bentuk perjanjian yang standar (kontrak baku) yaitu kontrak yang klausulklausulnya telah ditetapkan atau dirancang oleh satu pihak. ${ }^{8}$

\footnotetext{
${ }^{7}$ Pasal 1 angka 5 Undang-undang Republik Indonesia Nomor 1 Tahun 2013 Tentang Lembaga Keuangan Mikro

${ }^{8}$ Ahmadi Miru, 2007, Hukum Kontrak Perancangan Kontrak, Rajagrafindo Persada, Jakarta, hlm. 29.
} 


\begin{tabular}{llrr}
\hline \hline Volume: & 2 & E-ISSN: & $2655-1942$ \\
Number: & 2 & Terbitan: & November 2019 \\
Page : & $194-211$ & & \\
\hline
\end{tabular}

Pada prinsipnya hubungan antara nasabah penyimpan dana dengan Lembaga Keuangan Mikro Syariah merupakan hubungan kontraktual, maka tidak mengherankan dalam praktek jika seringkali pihak nasabah, terutama nasabah penyimpan dana tidak mendapatkan perlindungan yang semestinya oleh sektor hukum.

Selain hubungan tersebut, terdapat juga beberapa hubungan lainnya seperti hubungan moral. Hubungan moral tercipta ketika nasabah memberikan kepercayaannya kepada suatu Lembaga Keuangan Mikro Syariah. Hubungan kepercayaan antara nasabah penyimpan dengan Lembaga Keuangan Mikro Syariah yang terdapat dalam formulir-formulir yang diisi oleh nasabah penyimpan dan disetujui oleh Lembaga Keuangan Mikro Syariah biasa disebut dengan hubungan formil. ${ }^{9}$

Dalam formulir pada saat pembukaan tabungan maupun pada tabungan yang dikeluarkan oleh Lembaga Keuangan Mikro Syariah cenderung sangat sederhana dan tidak memuat adanya fasilitas pengaduan untuk nasabah penyimpan sehingga nasabah penyimpan tidak mengetahui adanya fasilitas tersebut, dalam prakteknya ketika nasabah kesulitan dalam melakukan penarikan dana akibat tingkat kesehatan Lembaga Keuangan Mikro Syariah memburuk, nasabah penyimpan hanya menunggu simpanan mereka dapat kembali meskipun Lembaga Keuangan Mikro Syariah menyerahkan simpanan nasabah penyimpan secara berkala.

Sehubungan dengan hal tersebut, jika mengacu pada Pasal 32 POJK.07/2013 Tentang Perlindungan Konsumen Sektor Jasa Keuangan dan Pasal 5 Peraturan Bank Indonesia Nomor 7/7/PBI/2005 Tentang Penyelesaian Pengaduan Nasabah, yang mengatur bahwa kewajiban suatu Bank untuk mempublikasikan

\footnotetext{
${ }^{9}$ Thy Widiyono, 2006, Aspek Hukum Operasional Transaksi Produk Perbankan di Indonesia, Ghalia Indonesia, Bogor, hlm. 30 .
} 


\begin{tabular}{|c|c|}
\hline $\begin{array}{l}\text { Volume: } \\
\text { Number: } \\
\text { Page : }\end{array}$ & $\begin{array}{rr}\text { E-ISSN: } & 2655-1942 \\
\text { Terbitan: } & \text { November } 2019\end{array}$ \\
\hline & $\begin{array}{l}\text { keberadaan unit dan atau fungsi khusus penanganan dan } \\
\text { penyelesaian pengaduan kepada masyarakat secara tertulis dan atau } \\
\text { elektronis. }\end{array}$ \\
\hline & $\begin{array}{l}\text { Berdasarkan hal tersebut, Otoritas Jasa Keuangan memberikan } \\
\text { jaminan perlindungan hukum bagi pengguna jasa lembaga } \\
\text { keuangan yang telah diatur dalam Pasal } 29 \text { Undang-undang Nomor } \\
21 \text { Tahun } 2011 \text { Tentang Otoritas Jasa Keuangan. Selain itu, Pasal } \\
26 \text { Undang-Undang Normor } 1 \text { Tahun } 2013 \text { Tentang Lembaga } \\
\text { Keuangan Mikro juga memberikan kepastian hukum serta } \\
\text { perlindungan hukum bagi pengguna jasa Lembaga Keuangan } \\
\text { Mikro. }\end{array}$ \\
\hline & $\begin{array}{l}\text { Maksud dari pasal diatas bahwa perlindungan yang dapat } \\
\text { diberikan Otoritas Jasa Keuangan kepada nasabah penyimpan } \\
\text { Lembaga Keuangan Mikro Syariah salah satunya ialah dengan cara } \\
\text { membuat mekanisme pengaduan penyimpan, akan tetapi dalam } \\
\text { kewenangan Otoritas Jasa Keuangan membuat mekanisme } \\
\text { pengaduan penyimpan masih belum dijelaskan bagaimana caranya } \\
\text { dan seperti apa bentuknya. }\end{array}$ \\
\hline
\end{tabular}

2. Peran OJK dalam perlindungan nasabah pada lembaga keuangan mikro syariah

Pada umumnya, konsumen bersifat memaksimumkan kepuasannya, dalam hal ini, Walker, E.R. lewat bukuya From Economic Theory to Policy (dalam Muhammad Nejatullah Siddiqi, 1991:94) menyatakan rasionalisasi ekonomi beranggapan bahwa para konsumen berusaha memaksimumkan 'kepuasan' mereka. ${ }^{10}$

OJK sebagai lembaga Negara yang dibentuk berdasarkan UndangUndang Nomor 21 Tahun 2011 tentang Otoritas Jasa Keuangan, berfungsi

${ }^{10}$ Lubis, Suhrawardi K., and Farid Wajadi. 2012. Hukum Ekonomi Islam. Sinar Grafika, Jakarta. 


\begin{tabular}{llrr}
\hline \hline Volume: & 2 & E-ISSN: & $2655-1942$ \\
Number: & 2 & Terbitan: & November 2019 \\
Page : & $194-211$ & & \\
\hline
\end{tabular}

menyelenggarakan sistem pengaturan dan pengawasan yang terintegrasi terhadap keseluruhan kegiatan di dalam sektor jasa keuangan baik di sektor perbankan, pasar modal, dan sektor jasa keuangan non-bank seperti Asuransi, Dana Pensiun, Lembaga Pembiayaan, dan Lembaga Jasa Keuangan lainnya. Terkait pengawasan lembaga jasa keuangan terhadap lembaga jasa keuangan bank maupun non-bank, OJK memiliki kewenangan ${ }^{11}$ antara lain:

1. Menetapkan kebijakan operasional pengawasan terhadap kegiatan jasa keuangan;

2. Mengawasi pelaksanaan tugas pengawasan yang dilaksanakan oleh Kepala Eksekutif;

3. Melakukan pengawasan, pemeriksaan, penyidikan, perlindungan konsumen dan tindakan lain terhadap lembaga jasa keuangan, pelaku, dan/atau penunjang kegiatan jasa keuangan sebagaimana dimaksud dalam peraturan perundang-undangan di sektor jasa keuangan;

4. Memberikan perintah tertulis kepada lembaga jasa keuangan dan/atau pihak tertentu;

5. Melakukan penunjukan pengelola statuter;

6. Menetapkan penggunaan pengelola statuter;

7. Menetapkan sanksi administratif terhadap pihak yang melakukan pelanggaran terhadap peraturan perundang-undangan di sektor jasa keuangan;

8. Memberikan dan/atau mencabut: izin usaha, izin orang perseorangan, efektifnya pernyataan pendaftaran, surat tanda terdaftar, persetujuan melakukan kegiatan usaha, pengesahan, persetujuan atau penetapan pembubaran dan penetapan lain.

OJK memiliki visi yakni menjadi lembaga pengawas industri jasa keuangan yang terpercaya, melindungi kepentingan konsumen dan

\footnotetext{
${ }^{11}$ https://www.ojk.go.id diakses pada tanggal 27 Juni 2019 pukul 15.50 WIB.
} 


\begin{tabular}{llrr}
\hline \hline Volume: & 2 & E-ISSN: & $2655-1942$ \\
Number: & 2 & Terbitan: & November 2019 \\
Page : & $194-211$ & & \\
\hline
\end{tabular}

masyarakat dan mampu mewujudkan industri jasa keuangan menjadi pilar perekonomian nasional yang berdaya saing global serta dapat memajukan kesejahteraan umum, untuk mewujudkan visinya adalah dengan salah satu misi OJK yaitu melindungi kepentingan konsumen dan masyarakat. Hal ini kemudian dipertegas lagi dengan strategi OJK yang termasuk dalam salah satu dari delapan strategi utama dalam rangka pencapaian visi dan misinya, yaitu dengan membangun sistem perlindungan konsumen keuangan yang terintegrasi dan melaksanakan edukasi dan sosialisasi yang masif dan komprehensif. Strategi ini diperlukan untuk mengefektifkan dan memperkuat bentuk-bentuk perlindungan konsumen yang selama ini masih tersebar, sehingga bersama sama dengan kegiatan edukasi dan sosialisasi akan mewujudkan level playing field yang sama antara lembaga jasa keuangan dengan konsumen keuangan ${ }^{12}$.

1. Perlindungan Nasabah Dalam Undang-Undang Nomor 1 Tahun 2013 Tentang Lembaga Keuangan Mikro

Undang-undang Nomor 1 Tahun 2013 tentang Keuangan Mikro menyebutkan bahwa pembinaan, pengaturan dan pengawasan LKM dilakukan oleh OJK yang didelegasikan kepada Pemerintah Daerah Kabupaten/Kota atau kepada pihak lain yang ditunjuk. Hal ini diatur secara rinci dalam Peraturan OJK Nomor 14/POJK.05/2014 Tentang Pembinaan dan Pengawasan Lembaga Keuangan Mikro.

Dalam Pasal 5 Peraturan OJK Tentang Pembinaan dan Pengawasan Lembaga Keuangan Mikro menyebutkan bahwa pembinaan dan pengawasan yang didelegasikan kepada Pemerintah Daerah Kabupaten/Kota atau pihak lain yang ditunjuk meliputi:

\footnotetext{
${ }^{12}$ https://www.ojk.go.id/id/Pages/Frequently-Asked-Questions-OJK.aspx, diakses pada tanggal 27 Juni 2019 pukul 20.27 WIB.
} 


\begin{tabular}{llrr}
\hline \hline Volume: & 2 & E-ISSN: & $2655-1942$ \\
Number: & 2 & Terbitan: & November 2019 \\
Page : & $194-211$ & & \\
\hline
\end{tabular}

a. Penerimaan laporan keuangan dan input data ke dalam sistem aplikasi;

b. Pelaksanaan analisis laporan keuangan LKM;

c. Penerimaan dan analisis laporan lain;

d. Pelaksanaan tindak lanjut atas laporan lainnya;

e. Penyusunan rencana kerja pemeriksaan, pelaksanaan pemeriksaan, dan tindak lanjut atas hasil pemeriksaan LKM;

f. Pengenaan sanksi administratif kepada LKM selain pencabutan izin usaha dan denda; dan

g. Pelaksanaan langkah-langkah penyehatan terhadap LKM yang mengalami kesulitan likuiditas dan solvabilitas yang membahayakan keberlangsungan usaha.

Perlindungan kepentingan pengguna jasa yang dilakukan LKM yaitu dengan menyediakan informsi terbuka kepada masyarakat sebagaimana ditegaskan dalam Pasal 24 Undang-undang tersebut. informasi tersebut antara lain mengenai:

a. Wewenang dan tanggung jawab pengurus LKM;

b. Ketentuan dan persyaratan yang perlu diketahui oleh Penyimpan dan Peminjaman; dan

c. Kemungkinan timbulnya risiko kerugian sehubungan dengan transaksi LKM dengan pihak lain. ${ }^{13}$

Untuk perlindungan pPenyimpan dan masyarakat, OJK memiliki wewenang melakukan tindakan pencegahan kerugian Penyimpan dan masyarakat serta melakukan pelayanan pengaduan Penyimpan. Dalam hal kewenangan OJK dalam melakukan tindakan pencegahan kerugian Penyimpan meliputi:

a. Memberikan informasi dan edukasi kepada masyarakat atas karakteristik dan kegiatan usaha LKM;

${ }^{13}$ Pasal 25, Undang-Undang Nomor 1 Tahun 2013 Tentang Lembaga Keuangan Mikro 


\begin{tabular}{llrr}
\hline \hline Volume: & 2 & E-ISSN: & $2655-1942$ \\
Number: & 2 & Terbitan: & November 2019 \\
Page : & $194-211$ & & \\
\hline
\end{tabular}

b. Meminta LKM untuk menghentikan kegiatannya apabila kegiatan tersebut berpotensi merugikan masyarakat; dan

c. Tindakan lain yang dianggap perlu sesuai dengan undangundang ini.

2. Pengawasan OJK Terhadap Lembaga Keuangan Mikro Syariah

OJK memiliki fungsi edukasi dan perlindungan konsumen. Hal ini telah diamatkan oleh Undang-undang kepada OJK mengenai edukasi dan perlindungan konsumen, yaitu mencegah kerugian masyarakat, melayani pengaduan konsumen, serta dalam hal pembelaan hukum. Perlindungan terhadap konsumen sangat penting dilakukan karena merupakan kebutuhan dasar serta untuk menjadi kepercayaan konsumen. Dan kepercayaan konsumen merupakan prasyarat dalam menjaga stabilitas dan pertumbuhan dalam jangka panjang ${ }^{14}$.

Pasal 29 Undang-Undang Nomor 21 Tahun 2011 Tentang Otoritas Jasa Keuangan menyebutkan bahwa OJK melakukan pelayanan pengaduan Konsumen yang meliputi penyiapan perangkat yang memadai, membuat mekanisme pengaduan konsumen, dan memfasilitsi penyelesaian pengaduan. Dalam mewujudkannya, Ketua Dewan Komisioner OJK telah meluncurkan program berupa Layanan Konsumen Terintegrasi OJK pada tanggal 6 Februari 2014. Layanan tersebut berupa permintaan dan penyampaian informasi serta layanan pengaduan.

Terdapat 5 (lima) masalah utama yang kerap kali dialami oleh konsumen/nasabah/ termasuk pengguna jasa lembaga keuangan mikro syariah, yaitu:

a. Informasi yang asimetris;

b. Perlakuan yang tidak adil;

${ }^{14}$ OJK. 2014. Mengenal OJK \& Lembaga Keuangan. Bandung: Bakohumas Information \& Communication Expo 2014. 


\begin{tabular}{llrr}
\hline \hline Volume: & 2 & E-ISSN: & $2655-1942$ \\
Number: & 2 & Terbitan: & November 2019 \\
Page : & $194-211$ & & \\
\hline
\end{tabular}

c. Kualitas layanan yang tidak memadai;

d. Penggunaan data pribadi konsumen; dan

e. Penanganan pengaduan yang kurang efektif.

Dengan adanya kelima masalah utama tersebut, maka diterbitkanlah Peraturan OJK Nomor 01/POJK.07/2013 Tahun 2013 Tentang Perlindungan Konsumen Sektor Jasa Keuangan. Penerbitan peraturan tersebut memiliki tujuan, yaitu sebagai payung hukum bagi pengaturan perlindungan konsumen sektor jasa keuangan di Indonesia serta mengatur prinsip perlindungan konsumen, yaitu prinsip transparansi; prinsip perlakuan yang adil; prinsip keandalan; prinsip perlindungan data konsumen; dan prinsip penanganan pengaduan dan penyelesaian sengketa konsumen.

Peraturan Otoritas Jasa Keuangan Nomor 1/POJK.07/2013 Tentang Perlindungan Konsumen Sektor Jasa Keuangan, memberikan pengertian Perlindungan Konsumen adalah perlindungan terhadap Konsumen dengan cakuan Pelaku Usaha Jasa Keuangan. Sedangkan Pelaku Usaha Jasa Keuangan dalam hal ini adalah Bank Umum, Bank Perkreditan Rakyat, Perusahaan Efek, Penasihat Investasi, Bank Kustodian, Dana Pensiun, Perusahaan Asuransi, Perusahaan Reasuransi, Lembaga Pembiayaan, Perusahaan Gadai, dan Perusahaan Penjaminan, baik yang melaksanakan kegiatan secara konvensional maupun secara syariah.

Dalam peraturan tersebut, pasal 48 ayat (1) ditegaskan bahwa Pelaku Usaha Jasa Keuangan wajib memiliki sistem pengawasan bagi Direksi atau pengurus dalam rangka perlindungan 


\begin{tabular}{llrr}
\hline \hline Volume: & 2 & E-ISSN: & $2655-1942$ \\
Number: & 2 & Terbitan: & November 2019 \\
Page $:$ & $194-211$ & & \\
\hline
\end{tabular}

Konsumen ${ }^{15}$. Hal ini menunjukkan bahwa kewajiban pengawasan terhadap lembaga keuangan mikro syariah tidak hanya dilakukan oleh OJK tetapi juga dilakukan oleh lembaga keuangan mikro syariah itu sendiri. Selain pengawasan terhadap kinerja Direksi atau pengurus, dalam peraturan OJK tersebut juga mengatur mengenai pengawasan terhadap perlindungan konsumen sektor jasa keuangan. OJK melakukan pengawasan kepatuhan Pelaku Usaha Jasa Keuangan terhadap penerapan ketentuan perlindungan konsumen secara langsung maupun tidak langsung.

\section{Kesimpulan dan Saran}

Perlindungan terhadap konsumen sangat penting dilakukan karena merupakan kebutuhan dasar serta untuk menjada kepercayaan konsumen. Dalam hal pembinaan, pengaturan dan pengawasan terhadap lembaga keuangan mikro syariah maupun konvensional baik yang berbadan hukum koperasi maupun perseroan terbatas, dilakukan oleh Otoritas Jasa Keuangan (OJK) yang didelegasikan kepada Pemerintah Daerah Kabupaten/Kota atau pihak lain yang ditunjuk. Peran OJK dalam hal perlindungan nasabah adalah dalam bentuk pelayanan pengaduan Konsumen yang meliputi penyiapan perangkat yang memadai, membuat mekanisme pengaduan Konsumen, dan memfasilitsi penyelesaian pengaduan. OJK melakukan pengawasan kepatuhan Pelaku Usaha Jasa Keuangan terhadap penerapan ketentuan perlindungan konsumen secara langsung maupun tidak langsung.

Dalam tulisan ini, penulis mengajukan rekomendasi/saran kepada OJK sebagai lembaga Negara yang berfungsi menyelenggarakan sistem pengaturan dan pengawasan yang terintegrasi terhadap keseluruhan kegiatan di dalam sektor jasa keuangan dalam hal perlindungan nasabah/konsumen pada lemaga keuangan mikro syariah, yaitu:

\footnotetext{
${ }^{15}$ Pasal 48 ayat (1) Peraturan Otoritas Jasa Keuangan Nomor: 1/POJK.07/2013 Tentang Perlindungan Konsumen Sektor Jasa Keuangan
} 


\begin{tabular}{llrr}
\hline \hline Volume: & 2 & E-ISSN: & $2655-1942$ \\
Number: & 2 & Terbitan: & November 2019 \\
Page : & $194-211$ & & \\
\hline
\end{tabular}

1) OJK harus terus inovatif dalam meningkatkan perlindungan nasabah/konsumen dengan memperkuat kerjasama dengan instansi-instansi terkait;

2) Memberikan respon kepada publik dengan baik dengan cara aktif menjalin komunikasi kepada nasabah lembaga keuangan mikro syariah maupun masyarakat luas agar;

3) Aktif melakukan kegiatan sosialisasi kepada masyarakat mengenai eksistensi, peran, dan tupoksi OJK untuk lembaga keuangan masyarakat syariah.

\section{DAFTAR PUSTAKA}

\section{Buku}

Arsyad, Lincolin, 2008, Lembaga Keuangan Mikro Institusi Kinerja dan Sustanbilitas, Andi, Yogyakarta.

Hadjon, Philipus M, 1987, Perlindungan Hukum Bagi Rakyat Indonesia, Bina Ilmu, Surabaya.

Lubis, Suhrawardi K., dan Farid Wajadi, 2012, Hukum Ekonomi Islam, Sinar Grafika, Jakarta.

Miru, Ahmadi, 2007, Hukum Kontrak Perancangan Kontrak, Rajagrafindo Persada, Jakarta.

Widiyono, Thy, 2006, Aspek Hukum Operasional Transaksi Produk Perbankan di Indonesia, Ghalia Indonesia, Bogor.

\section{Makalah/Pidato}

OJK, "Mengenal OJK \& Lembaga Keuangan”. Bakohumas Information \& Communication Expo, Bandung, 2014.

\section{Internet}




\begin{tabular}{llrr}
\hline \hline Volume: & 2 & E-ISSN: & $2655-1942$ \\
Number: & 2 & Terbitan: & November 2019 \\
Page : & $194-211$ & & \\
\hline
\end{tabular}

OJK, "Roadmap Industri Keuangan Non-Bank (IKNB) Syariah 2015-2019", https://www.ojk.go.id/id/kanal/syariah/berita-dan-

kegiatan/publikasi/Pages/Roadmap-Pasar-IKNB-2015-2019.aspx, diakses pada tanggal 27 Juni 2019 pukul 20.00 WIB.

OJK, "Frequently Asked Questions Otoritas Jasa Keuangan", https://www.ojk.go.id/id/Pages/Frequently-Asked-Questions-OJK.aspx, diakses pada tanggal 27 Juni 2019 pukul 20.27 WIB.

\section{Undang-Undang}

Undang-Undang Nomor 1 Tahun 2013 Tentang Lembaga Keuangan Mikro (Lembaran Negara Republik Indonesia Tahun 2013 Nomor 12, Tambahan Lembaran Negara Republik Indonesia Nomor 5394) 